\title{
Soil Drainage and Nutrient Management to Improve Productivity of Waterlogged Vertisols for Small-scale Farmers
}

\author{
Meles Mekonen ${ }^{1}$, Kindie Tesfaye ${ }^{2}$, \& Wondimu Bayu ${ }^{3}$ \\ ${ }^{1}$ Wollo University, Dessie, Ethiopia. \\ ${ }^{2}$ Haramaya University, Ethiopia. \\ ${ }^{3}$ ICARDA, Bahir Dar, Ethiopia
}

\begin{abstract}
Vertisols cover large part of the high rainfall areas of Ethiopia. However, the potential of these soils is not well exploited because of heavy water logging during the main rain season. A study was conducted to investigate the interactive effects of soil drainage and fertilizer application on the productivity of Vertisols. Factorial combinations of four planting beds (Broadbed and furrow (BBF) with $100 \mathrm{~cm}$ bed size, broadbed and furrow with $80 \mathrm{~cm}$ bed size, ridge and furrow (RF) with $30 \mathrm{~cm}$ bed size, and flatbed) and two fertilizer levels (unfertilized and fertilized with $64 \mathrm{~kg} \mathrm{~N}$ ha-1 \& 46 kg P2O5 ha-1) in RCBD were experimented for the sustainable use and improved productivity of Vertisols in Northeastern Ethiopia in the 2006/2007 cropping season. Results revealed that ridge and furrow bed (RF) drained more excess water than the broadbed and furrow beds (BBF) and the flatbed $(\mathrm{F})$, but with yield penalties. Soil drainage using broadbed and furrows (BBF) and nitrogen and phosphorus fertilization reduced days to heading and maturity by 12 and $15 \%$, respectively. The broadbed and furrow and the nitrogen and phosphorus fertilization package increased grain yield by $90 \%$, grain nitrogen and phosphorus uptakes by 183 and $252 \%$, and stover nitrogen and phosphorus uptakes by 152 and $121 \%$. Thus, planting in broadbed and furrows (BBF), disregard of the bed size, with fertilizer application is recommended for bread wheat production on vertisols in Northeastern Ethiopia.
\end{abstract}

Key words: Broadbed and furrow, grain yield, nutrient uptake, water logging

\section{INTRODUCTION}

In Ethiopia, Vertisols cover about 12.6 million ha of land, or about $10 \%$ of the total area of the country (Getachew et al., 1993; Jutzi, 1989). These soils have great potential for crop production since they have relatively good inherent fertility and are located mainly in the highlands where rainfall is plenty. However, due to the inherent physical characteristics of these soils coupled with high rainfall, yield is low mainly due to waterlogging. An old data showed that out of the 7.6 million hectares of Vertisols found in the highlands only 2 
million hectares were under cultivation mainly due to waterlogging (Getachew et al., 1993). In Delanta District too, Vertisols have large coverage where they account for $85 \%$ of the total area (Getaw, 2000), and are underutilized due to waterlogging. It is long established that waterlogging results in poor aeration, lower soil microbial activities, loss and unavailability of plant nutrients and poor workability (Trough and Drew, 1982).

Generally, Vertisols are important agricultural soils in the Ethiopian highlands and are productive but difficult to manage due to their poor internal drainage and resultant waterlogging (Jutzi and Abebe, 1987). Consequently, Vertisols in Ethiopia are currently underutilized. Waterlogging adversely affects the growth of crops, primarily due to reduced oxygen supply to the roots (Armstrong, 1982 cited by Amsal et al., 2000). Moreover, nitrogen availability can be seriously lowered in waterlogged soils due to denitrification caused by anaerobic soil bacteria (Cook and Veseth, 1991 cited by Yesuf et al., 2000). The root tips, where most water, air and nutrient uptake takes place, are the first to suffer from waterlogging mainly due to lack of oxygen reducing the seminal root growth in particular (van Ginkel et al., 1991). As a result of this, the crop roots are poorly aerated and nutrient uptake for growth and development will be impaired (McDonald and Gardner, 1987). According to McDonald and Gardner (1987), waterlogging during tillering and stem elongation leads to fewer tillers, more floral sterility, fewer grains per spike, reduced kernel weight and a final yield loss of $50 \%$ or more.

To overcome the waterlogging stress, farmers in Ethiopia traditionally plant late in the season. However, planting late in the season has yield penalty as the crop would be exposed to terminal moisture stress and frost damage (Jutzi and Abebe, 1987; Teklu et al., 2005). While Vertisols remain underutilized, population pressure has pushed crop production and livestock grazing to steep slopes causing serious devegetation and soil erosion. Considering their large moisture-holding capacity and relatively high fertility, Vertisols are capable of producing many times more food and livestock feed than they do today. Therefore in food deficit Ethiopia, removing constraints to crop production in Vertisol areas is of very high importance (Tekalign et al., 1993). If food security is to be achieved in Ethiopia, Vertisols which cover immense land mass of the country, needs to be put under cultivation with excess water draining innovations. Furthermore, it has been reported that removal of excess water from Vertisols significantly enhance nutrient uptake in crops (Asnakew et al., 1991). Thus, this study hypothesized that early planting and increased productivity of Vertisols could be achieved through complementary contributions of improved soil drainage and use of mineral fertilization. Therefore, this study was conducted to investigate the interactive effects of soil drainage and fertilizer application on the yield and yield components and nutrient uptake of wheat in a typical Vertisol in a highland area.

\section{MATERIALS AND METHOdS}

\section{Description of the study area}

The experiment was conducted in the 2006/07 main cropping season at Delanta, which is located at $11^{\circ} 35^{\prime} \mathrm{N}$ latitude, $39^{\circ} 12^{\prime}$ E longitude and altitude of 2850 masl in North Wollo Administrative Zone of the Amhara National Regional State. Based on 10 years (19962005) climatic data, the area receives an average annual rainfall of $776.7 \mathrm{~mm}$ of which $72.2 \%$ is received during the main rain season (June to September). The highland plateau of Delanta has very cold temperature which ranges from 0 to $20{ }^{\circ} \mathrm{C}$ (Getaw, 2000). The dominant soil in Delanta is Vertisol which is a black to gray clay soil with high swelling and shrinking character. It is poorly drained when wet and cracking when dry. The 
Vertisol in the study area has slightly alkaline $\mathrm{pH}(7.6)$ with very low OC (1.476\%), and low total $\mathrm{N}(0.119 \%)$ and available P (3 ppm) contents.

\section{Treatments and experimental design}

Treatments were factorial combinations of four planting beds and two fertilizer levels (unfertilized and fertilized with $64 \mathrm{~kg} \mathrm{~N} \mathrm{ha}^{-1} \& 46 \mathrm{~kg} \mathrm{P}_{2} \mathrm{O}_{5} \mathrm{ha}^{-1}$ ). The four planting beds were: broadbed and furrow (BBF) with effective bed width of $100 \mathrm{~cm}$ and $20 \mathrm{~cm}$ wide and deep drainage furrows $(100 \mathrm{~cm} \mathrm{BBF})$, broadbed and furrow with effective bed width of $80 \mathrm{~cm}$ and $20 \mathrm{~cm}$ wide and deep drainage furrows $(80 \mathrm{~cm} \mathrm{BBF})$, ridge and furrow with effective bed width of $30 \mathrm{~cm}$ and $20 \mathrm{~cm}$ wide and deep drainage furrows (RF) and flatbed (F) which is the farmers' practice. These beds are meant to facilitate surface drainage through the furrows between the beds so that the crops grow on the drained beds. The experimental design is Randomized Complete Block Design (RCBD) with three replications. Each plot had a size of $5 \mathrm{~m} \times 6 \mathrm{~m}\left(30 \mathrm{~m}^{2}\right)$. Broadcast planting was on the $7^{\text {th }}$ of July 2006 at the seed rate of $150 \mathrm{~kg}^{2} \mathrm{ha}^{-}$ ${ }^{1}$. BBF was constructed using the improved Broadbed and Furrow Maker (BBM) and the RF was constructed using the traditional ox-drawn tine-plough. Full dose of phosphorus in the form of DAP and half of the $\mathrm{N}\left(32 \mathrm{~kg} \mathrm{~N} \mathrm{ha}^{-1}\right)$ in the form of DAP and Urea were applied at planting. The remaining half of the $\mathrm{N}$ was top-dressed at tillering. A waterlogging dread wheat variety ET-13 (Amsal et al., 2000) was used for the study.

Data were collected on growth and yield parameters. Plant height was determined on 15 randomly taken plants from each plot. Yield and yield components were determined from $0.5 \mathrm{~m}^{2}$ area (two quadrant samples) at the centre of each plot. Spike length, number of spikelets per spike and number of kernels per spike were taken from 15 randomly taken spikes from the sampled quadrant area. Grain yield was adjusted to $12.5 \%$ moisture content. Grain moisture content was determined using the GAC 2100 Grain Analysis apparatus (Decky-John Corp.).

After maturity, randomly taken plants from $0.5 \mathrm{~m} \times 0.5 \mathrm{~m}$ quadrant per net plot were harvested at ground level, air-dried and partitioned into straw and grain. The grain and straw samples were ground, sieved through $1 \mathrm{~mm}$ sieve and the sample used for $\mathrm{N}$ and $\mathrm{P}$ content determination. The $\mathrm{N}$ and $\mathrm{P}$ contents of the grain and straw were determined by the Kjeldahl and wet digestion methods, respectively.

Soil samples were collected from five representative spots within the experimental field at a depth of 0-30 cm before planting to make composite samples for each analysis. Soil texture was determined using hydrometer method (Jackson, 1958) and the $\mathrm{pH}$ of the soil was measured potentiometrically in the supernatant suspension of a 1:2.5 soil:water mixture using a $\mathrm{pH}$ meter. Organic carbon was determined following the Walkely and Black wet oxidation method (Jackson, 1958). Total $\mathrm{N}$ was determined using Kjeldahl method (Jackson, 1958), while available $\mathrm{P}$ was extracted with sodium bicarbonate solution at a $\mathrm{pH}$ of 8.5 following the procedure described by Olsen and Sommer (1982). Soil water content was determined gravimetrically at two depths $(0-30 \mathrm{~cm}$ and $30-60 \mathrm{~cm})$ using a core sampler at the flowering, seed setting and maturity stages. Bulk density $\left(\mathrm{g} \mathrm{cm}^{-3}\right)$ of the soil was determined from the dried soil sampled using a core sampler. The soil water $(\mathrm{mm})$ was then determined by suing the $\phi$ value multiplied by the bulk density and the depth of measurement (D).

Grain and straw $\mathrm{N}$ and P uptake (GNU, GPU, SNU, and SPU) were calculated by multiplying the grain and straw yields by the respective tissue $\mathrm{N}$ and $\mathrm{P}$ contents. Then, apparent recovery of the nutrient applied was calculated from the total nutrient uptake values following Pal (1991) as: 


$$
A N R / A P R=\frac{(U n-U o)}{n} * 100
$$

Where; ANR/APR are apparent nitrogen or phosphorus recovery, Un is nutrient uptake at ' $\mathrm{n}$ ' rate of fertilizer, and Uo is nutrient uptake at control (no fertilizer nutrient applied).

Finally, data were subjected to analysis of variance using SAS statistical software, version 8.2 (SAS Institute Inc., USA). Whenever treatment differences were significant, means were separated using the Least Significant Difference (LSD) Test.

\section{Results AND Discussions}

\section{Soil water contents}

Soil water content at $0-30 \mathrm{~cm}$ and $30-60 \mathrm{~cm}$ depths at flowering, heading and maturity showed significant differences $(\mathrm{P} \leq 0.01)$ between planting beds. At both depths, soil water was significantly higher in the flatbed followed by the BBF. The RF beds were highly drained at the $30 \mathrm{~cm}$ soil depth throughout the season and at $60 \mathrm{~cm}$ depth at maturity (Fig. 1). The $100 \mathrm{~cm} \mathrm{BBF}$ and $80 \mathrm{~cm}$ BBF had similar soil water content throughout the season indicating that a $20 \mathrm{~cm}$ difference on the bed size had no significant effect on soil drainage (Fig. 1). Flatbed showed, expectedly, the highest soil water content. The better soil drainage observed in the RF beds is due to the large number of furrows at closer spacing per unit area, which drained the excess water out of the field. Nevertheless, the good drainage was at the expense of plant population per unit area as compared to the other planting beds owing to many drainage furrows per unit area.

\section{Crop Growth and development}

\section{((Figure 1))}

Days to heading and physiological maturity were significantly $(P \leq 0.05)$ affected by the interaction effects of planting bed and fertilization (Table 1). Results revealed that plants in the 80 and $100 \mathrm{~cm}$ beds with fertilizer application headed and matured significantly earlier than plants which received fertilizer but planted on ridge and furrow and flatbeds and also over plants on similar beds that did not receive fertilizer (Table 2). Plants which were planted on drained soils (100 and $80 \mathrm{~cm}$ beds) and received fertilizer headed and matured by 11 and 25 days earlier, respectively compared to plants grown on flatbed without fertilization. This result is in agreement with the reports of Salisbury and Ross (1992) who reported that crop growth was negatively affected by planting beds and fertilization.

Plant height is also significantly $(\mathrm{P} \leq 0.01)$ affected by the interaction effects of treatments (Table 1) where plants in the fertilized and drained plots grow significantly taller than plants in plots without fertilization and drainage (Table 2) where fertilization and soil drainage has increased plant height by as much as $20 \%$. Both under fertilized and unfertilized conditions, plants on BBF plots had taller height than plants in the RF and flatbeds. Similarly, Yesuf et al. (2000) have reported increased plant height in wheat by as high as $24 \%$ in BBF over flatbed planting.

\section{Yield components}

((Tables $1 \& 2))$

Number of spikes and spike length were significantly affected by the interaction effects of planting bed and fertilization (Table 1). Plants grown on the 80 and $100 \mathrm{~cm}$ beds with fertilizer application had the highest spike number and spike lengths (Table 3). Generally, across all planting beds plants which received fertilizer have significantly higher number 
and length of spikes as compared to the unfertilized plots (Table 3). The 100 and $80 \mathrm{~cm}$ wide planting beds with fertilizer application increased spike number by 88 to $96 \%$ and spike length by up to $37 \%$ over the control (Tables 3). The RF treatment had the lowest number of spikes under fertilized and unfertilized conditions, which is due to low plant population resulted from land wastage due to the narrow furrow construction. Number of spikletes per spike responded to the main effects of fertilization and planting bed (Table 1), where soil drainage using 100 and $80 \mathrm{~cm}$ BBF has significantly increased the number of spikletes spike $^{-1}$ by up to $18 \%$ (Table 3 ). Fertilization also has increased the number of spikletes spike ${ }^{-1}$ from 14.8 to 16.6 which is an increase of $12 \%$ due to fertilization.

((Table 3))

Number of kernels per spike and thousand kernel weight were significantly $(\mathrm{P} \leq 0.01)$ affected by the interaction effects of planting bed and fertilization (Table 4). Soil drainage with 80 and $100 \mathrm{~cm}$ wide beds with fertilizer application have given significantly higher number of kernels per spike and thousand kernel weight over the other combinations. Plants in a similar soil drainage beds but did not receive fertilizer have given significantly lower kernel number and thousand kernel weight (Table 5). The importance of $\mathrm{N}$ fertilizer in determining the final grain yields of wheat through its effect on rate of spikelet initiation, spikelet fertility, number of grains per fertile spikelet and biomass formation has been reported by Frank and Bauer (1982).

The number of kernels per spike ranged from 46.4 in the flatbed under unfertilized condition to 71.2 in the $80 \mathrm{~cm} \mathrm{BBF}$ under fertilized condition. Similarly, thousand kernel weight ranged from 42.4 in the flatbed under unfertilized condition to 46.7 in the $80 \mathrm{~cm}$ BBF under fertilized condition. Both number of kernels per spike and thousand kernel weight were not significantly affected by fertilization treatments in the flatbeds which magnifies the fact that application of fertilizer under waterlogged conditions could not have positive effect on the productivity of the crop. This agrees with the report of Belford (1981) who reported the negative effect of waterlogging on grain number, size and weight of wheat.

\section{Biomass and grain yield}

((Tables 4 \& 5))

Aboveground biomass and grain yields and harvest index were significantly $(P \leq 0.01)$ influenced by the interaction effects of planting bed and fertilization (Table 4). Draining the soil with 80 and $100 \mathrm{~cm}$ wide beds with fertilizer application gave higher aboveground biomass and grain yields and harvest index over the other combinations (Table 6). Relative to the flatbed, aboveground biomass yield increased by 36,38 and $2 \%$ in the $100 \mathrm{~cm} \mathrm{BBF}$, $80 \mathrm{~cm}$ BBF and RF beds, respectively under fertilized condition and by 7,7 and $2 \%$ under unfertilized condition, respectively. Grain yield also increased by 64,67 and 3\% under fertilized condition and by 23, 26 and 3\% under unfertilized condition. Significant differences between the $80 \mathrm{~cm}$ and $100 \mathrm{~cm}$ BBF beds and between the RF and flatbed were not observed in the current study. Plants in a similar planting beds but did not receive fertilizer have given significantly lower biomass and grain yields and harvest index, indicating that fertilization should be an integral part of the effort in improving the productivity of Vertisols. This result is in agreement with the results of Schulthess et al. (1997) who reported significant increase in grain yield and grain $\mathrm{N}$ and P concentration of wheat in Vertisols with the application of nitrogen and phosphorus fertilizers.

Similar to the current results, several workers also reported the favourable effect of broadbed and furrow beds on grain yield of different crops under waterlogged soils. 
Belayneh (1986) and Jutzi and Abebe (1987) reported up to 54 to $300 \%$ increase in grain yield by growing wheat on BBF beds. Abate et al. (1993) reported 58\% yield increase in durum wheat and $106 \%$ in chickpea and lentil when planted on BBF over planting on flatbed. Abebe et al. (1994) also reported significantly increased grain and straw yields of durum wheat, chickpea and lentil with BBF comparing with ridge and furrow and flat bed planting. Selvaraju et al. (1999) evaluated land configuration practices (BBF; compartmental bunding, $\mathrm{CB}$; ridging, $\mathrm{RD}$; and flat bed, FB) in a Vertisol in India and reported 34\% and 33\% more grain yield of sorghum and pearl millet, respectively with BBF over FB. Yesuf et al. (2000) also reported yield increases of $660-1200 \mathrm{~kg} / \mathrm{ha}$ and $170-700 \mathrm{~kg} / \mathrm{ha}$ in bread wheat with BBF and RF surface drainage methods over flatbed, respectively at two sites. Teklu et al. (2006) compared four methods of Vertisol management (BBF, green manure, ridge and furrow and reduced tillage) and reported 59\% increase in the grain yield of lentils with BBF compared to the control (ridge and furrow). They also reported BBF as the most profitable option for lentil with $65 \%$ increase in total gross margin.

Improved soil nutrient management is also indicated to increase productivity of Vertisols, especially if it is combined with soil drainage. Abate et al. (1993) reported increased $\mathrm{N}$ use efficiency in an improved durum wheat variety planted on BBF where $\mathrm{N}$ use efficiency ranged from 7.1 to $17.3 \mathrm{~kg}_{\text {grain }} \mathrm{kg}^{-1} \mathrm{~N}$ in BBF compared to 0.9 to $10.8 \mathrm{~kg}_{\text {grain }} \mathrm{kg}^{-1} \mathrm{~N}$ for flatbed. Ramesh et al. (2002) studied the effects of three nitrogen levels $(0,75$ and $100 \%$ of the recommended dose of nitrogen) on the dry matter accumulation (DMA) and productivity of three cropping systems (sole soybean, sole sorghum and soybean + sorghum intercropping) during the rainy season and their residual effect on the subsequent wheat crop during the post-rainy season on a deep Vertisols of Bhopal, India and reported that increasing the $\mathrm{N}$ dose from 0 to $100 \%$ had significantly improved the DMA and application of $100 \%$ RDN irrespective of cropping system during the preceding crop improved the DMA of wheat but not its seed yield. However, N applied to the wheat crop significantly increased its DMA and seed yield.

\section{((Table 6))}

\section{Grain and straw nitrogen and phosphorus uptakes}

Waterlogging of soil may restrict crop performance by altering soil mineral nutrient availability to and uptake by roots. In Vertisols the roots of the crops are often poorly aerated and nutrient uptake is often reported to be impaired. Improved soil drainage in Vertisols is reported to largely contribute to improved nutrient uptake and plant growth. In the current study grain and straw nitrogen and phosphorus uptakes were significantly $(\mathrm{P} \leq 0.01)$ affected by the interaction effects of soil drainage and fertilization (Table 7$)$.

\section{((Table 7))}

Grain and straw nitrogen and phosphorus uptakes were significantly higher for the $100 \mathrm{~cm}$ and $80 \mathrm{~cm}$ beds which received fertilizer application (Table 8). The flat seedbed gave the lowest grain and straw $\mathrm{N}$ and $\mathrm{P}$ uptake under both fertilized and unfertilized conditions (Table 8). Relative to the flatbed, grain $\mathrm{N}$ uptake increased by 85,89 and $14 \%$ under fertilized condition and by 29,37 and 12\% under unfertilized condition in the $100 \mathrm{~cm}$ and $80 \mathrm{~cm}$ beds and RF beds, respectively. Similarly, straw N uptake increased by 67,67 and $29 \%$ under fertilized condition and by 21, 20 and $24 \%$ under unfertilized condition in the $100 \mathrm{~cm}$ and 80 $\mathrm{cm}$ beds and RF beds, respectively. Grain P uptake also increased by 113,115 , and $9 \%$ under fertilized condition and by 59,62 and 18\% under unfertilized condition over the flatbed. 
Straw P uptake increased by 49,49 and 13\% under fertilized condition and by 31,34 and 17\% under unfertilized condition. Similarly, Sigunga et al. (2002), in their study to determine the effects of drainage, $\mathrm{N}$ source and time of application on yields, nutrient uptake and utilization efficiencies by maize grown on Vertisols, they reported that drainage resulted in total $\mathrm{N}$ uptake increases from 50 to $80 \mathrm{~kg} \mathrm{~N} \mathrm{ha}^{-1}$ in control plots, 80 to $130 \mathrm{~kg} \mathrm{~N} \mathrm{ha}^{-1}$ in NO3-N treated plots, and 90 to $130 \mathrm{~kg} \mathrm{~N} \mathrm{ha}^{-1}$ in NH4-N treated plots.

((Table 8))

The highest grain yield was obtained from plants grown on $100 \mathrm{~cm}$ and $80 \mathrm{~cm}$ beds, where the grain $\mathrm{N}$ and $\mathrm{P}$ uptakes were the maximum. Conversely, the lowest grain yield was obtained from ridge and furrow followed by flat seedbed at which grain $\mathrm{N}$ and $\mathrm{P}$ uptakes were at minimum. The lowest straw and grain $\mathrm{N}$ and $\mathrm{P}$ uptakes observed in the flatbed indicate the significant effect of waterlogging in reducing plant nutrient uptake in Vertisols. Therefore, the significant differences observed in grain and straw $\mathrm{N}$ and $\mathrm{P}$ uptake among planting beds could be related to the difference in the capacity of the different drainage beds to drain water out of the crop field. The decline in grain and straw $\mathrm{N}$ and $\mathrm{P}$ concentration observed in the waterlogged plants (flatbed) suggest that $\mathrm{N}$ and $\mathrm{P}$ absorption and transportation was significantly suppressed by oxygen deficiency in the soil which impaired root functioning and energy supply for ion uptake (Amsal et al., 2000). Similarly, Amsal et al. (2000) in their study to determine the effects of soil waterlogging on $\mathrm{Cu}, \mathrm{Zn}, \mathrm{P}$ and $\mathrm{K}$ nutrient concentration and uptake by wheat genotypes reported that total plant uptake of these nutrients was highly reduced which they attributed to depressed root zone oxygenation due to waterlogging.

\section{Apparent nitrogen (ANR) and phosphorus (APR) recovery}

Analysis of variance indicated that apparent $\mathrm{N}$ and $\mathrm{P}$ recovery were significantly $(\mathrm{P} \leq 0.01)$ affected by planting bed types (Table 9). The highest significant $\mathrm{N}$ and $\mathrm{P}$ apparent recoveries were recorded for $100 \mathrm{~cm}$ and $80 \mathrm{~cm}$ beds (Table 10). The lowest ANR and APR were observed in the flat seedbed indicating the significant effect of waterlogging on fertilizer recovery. This indicates the importance of draining excess water on Vertisols in order to increase uptake and utilization of nutrients by bread wheat. Planting in $100 \mathrm{~cm}$ and $80 \mathrm{~cm}$ BBF beds improved ANR by 2.4 and $2.5 \%$ and APR by 2.3 and $2.4 \%$, respectively over the flatbed planting. Similarly, Syers et al. (2001) reported substantial increase in nutrient removal and fertilizer nutrient use efficiency with improved soil water management using land forming techniques in Ghana with the prospect of obtaining higher yields for a given level of nutrient input, or maintaining crop yield with a reduced input.

Nutrient uptake efficiency or apparent recovery is a measure of the ability of the crop to extract nutrients from the soil, that is, plant tissue nutrients as a proportion of supplied nutrient (Moll et al., 1982). Therefore, the highest NP recovery rates observed in the BBF treatments indicate the efficiency by which the applied nutrients are recovered under well drained conditions compared to less drained conditions.

\section{Conclusions}

The soil water content measured at different stages of the crop showed significant difference between soil drainage methods (planting beds). A ridge and furrow planting bed was effective in draining the excess water. This is because of large number of furrows in the RF that helped to drain excess water from the plots. 
Delay in days to heading and physiological maturity was observed in plants grown on flat seed bed which indicates that crop yield penalty could be experienced due to early cessation of the rain. According to the results of this study, farmers could double or triple the grain and straw yield of wheat by implementing simple soil drainage beds and applying fertilizers. Furthermore, if the market for quality wheat could be available farmers could get higher price from their wheat as the protein content of their wheat gets improved through soil drainage and fertilizer application.

From the result of the study, the package of broadbed and furrow and fertilizer application outperformed the ridge and furrow and flatbed in all the parameters measured. The effects of waterlogging on crop phenology and growth, biomass and grain yield and nutrient concentration was clearly reflected in the flatbed planting. Therefore, the package of broadbed and furrow and mineral fertilization is recommended as it reduces the energy and time required to make the soil drainage and gives higher yield compared to the ridge and furrow and flatbed planting.

\section{REFERENCES}

Abate, T., Mohamed-Saleem, M.A., Tekalign, M., Alemu, T., Miressa, D. (1993): Grain, fodder and residue management, In Tekalign, M., Abiye, A., Srivastava, K.L., Asgelil, D. (eds.). Improved management of Vertisols for sustainable crop-livestock production in the Ethiopian highlands: Synthesis report 1986-92. Technical Committee of the Joint Vertisol Project, Addis Ababa, Ethiopia, pp.103-137.

Abebe, M., Mamo, T., Duffera, M., Kidanu, S. (1994): Crop Response to Improved Drainage of Vertisols in the Ethiopian Highlands. J. Agron. Crop Sci. 172, 217-222.

Amsal, T., Bennie, A.T.P., Labuschagne, M.T. (2000): The concentration and uptake of selected nutrients by wheat genotypes differeing in tolerance, In The Eleventh Regional Wheat Workshop for Eastern, Central and Southern Africa. CIMMYT, Addis Ababa, Ethiopia, pp. 253-263.

Asnakew, W., Tekaligne, M., Mengesha, B., Tefera, A. (1991): Soil fertility management studies on wheat in Ethiopia, In Hailu, G., Douglas, G.T., Mengistu, H. (eds.): Wheat research in Ethiopia: A historical perspective. IAR/CIMMYT, Addis Abeba, Ethiopia.

Belayneh, H. (1986): The effects of drainage systems, drainage spacings and fertilizer on seed yield and other characters of wheat, tef and chickpea on heavy soils of Ginchi. Ethiopian J. Agric. Sci. 2, 85-93.

Belford, R.K. (1981): Response of winter wheat to prolonged waterlogging under outdoor condition. J. Agric. Sci. (Camb.) 97, 557-568.

Frank, A.B., Bauer, A. (1982): Effects of temperature and fertilizer $\mathrm{N}$ on apex development in spring wheat. Agron. J. 74, 504-509.

Getachew, A., Hailu, B., Workeneh, N., Gezahegn, A. (1993): A Survey of the Farming Systems of Vertisol Areas of the Ethiopian Highlands, In Mamo, T., Astatke, A., Srivastava, K.L., Asgelil, D. (eds.): Improved Management of Vertisols for Sustainable Crop-Livestock Production in the Ethiopian Highlands: Synthesis Report 1986-92. Technical Committee of the Joint Vertisol Project, Addis Ababa, Ethiopia, pp. 29-49.

Getaw, T. (2000): Farming systems of Delanta district and Farmers Participatory Research interventions: Result of field visits and research proposal. Sirinka Agricultural Research Center in collaboration with Oxfam-GB Delanta Project, Sirinka, Ethiopia.

Jackson, M.L. (1958): Soil Chemical Analysis Practice. Hall of India, New Delhi.

Jutzi, S.C. (1989): The Ethiopian Vertisols: A vast natural resource but considerably underutilized. In Proceedings of the First Natural Resources Conservation Conference. Natural Resources Degradation: A Challenge to Ethiopia, 7-8 February 1989, Addis Ababa, Ethiopia, pp. 41-46.

Jutzi, S.C., Abebe, M. (1987): Improved agricultural utilization of Vertisols in the Ethiopian highlands an inter institutional approach. In Latham, M., Ahn, P., Elliott, C.R. (eds.) Management of Vertisols 
under Semi-Arid Conditions, Proceeding of the first Regional Seminar. IBSRAM, Bangkok, pp. 173-183.

McDonald, G.K., Gardner, W.K. (1987): Effect of waterlogging on the grain yield of wheat. Aust. J. Exp. Agri. 27, 661-670.

Moll, R.H., Kamprath, E.J., Jackson, W.A. (1982): Analysis and interpretation of factors which contribute to efficiency of nitrogen utilization. Agron. J. 74, 562-564.

Olsen, S.R. and L.E. Sommer, 1982. Phosphorus In Page, A.L., Miller, R.H., Keeneys, D.R. (eds.): Method of soil analysis. Chemical and biological properties; American Society of Agronomy 9: 403-430.

Pal, U.R. (1991): Effects of source and rate of nitrogen and phosphorus on yield and nutrient uptake and apparent fertilizer recovery by maize in the southern Guina Savana. J. Agric. Sci. Techn. 1, 21-24.

Ramesh, P., Ajay, G.P.K., Ramana, S. (2002) Effects of Nitrogen on Dry Matter Accumulation and Productivity of Three Cropping Systems and Residual Effects on Wheat in Deep Vertisols of Central India. J. Agron. Crop Sci. 188, 81-85.

Salisbury, F.B., Ross, C.W. (1992): Plant Physiology. $4^{\text {th }}$ ed. Wada worth publishing company, Belmont, California, p. 102-107.

Schulthess, U., Feil, B., Jutzi, S.C. (1997): Yield independent variation in grain nitrogen and phosphorus concentration among Ethiopian wheat. Agron. J. 89, 497-506.

Selvaraju, R., Subbian, P., Balasubramanian, A., Lal, R. (1999): Land configuration and soil nutrient management options for sustainable crop production on Alfisols andVertisols of southern peninsular India. Soil Till. Res. 52, 203-216.

Sigunga, D.O., Janssen B.H., Oenema, O. (2002): Effects of improved drainage and nitrogen source on yields, nutrient uptake and utilization efficiencies by maize (Zea mays L.) on Vertisols in subhumid environments. Nut. Cycl. Agroecosy. 62, 263-275.

Syers, J.K., Nyamudeza, P., Ahenkorah, Y. (2001): Sustainable nutrient management of vertisols. In: Syers, J. K., Penning de Vries, F.W.T., Nyamudeza, P. (eds.): The sustainable management of vertisols. CABI, New York, USA. pp.43-56.

Tekalign, M., Abiye, A., Srivastavn, K.L., Asgelil, D. (1993). Improved management of vertisols for sustainable crop-livestock production in the Ethiopian highlands. Synthesis Report 1986-92. Technical Committee of the Joint Vertisol Project, Addis Ababa, Ethiopia.

Teklu E., Stahr, K., Gaiser, T. (2006). Soil tillage and crop productivity on a Vertisol in Ethiopian highlands. Soil Till. Res. 85, 200-211.

Teklu, E. (2005): Land preparation methods and soil quality of a Vertisol area in the central highlands of Ethiopia. Ph.D. Thesis, Universitat Hohenheim, Germany.

Teklu, E., Stahr, K., Gaiser, T. (2005): Effect of different methods of land preparation on runoff, soil and nutrient losses from a vertisol in the Ethiopian highlands. Soil use Mgmt. 21, 253-259.

Trough, M.C.T., Drew, M.C. (1982): Effects of waterlogging on young wheat plants (Triticum aestivum L.) and on soil solutes at different soil temperatures. Plant and Soil 69, 311-326.

Van Ginkel M., Rajaram, S., Thijssen, M. (1991): Water logging in wheat: Germplasm evaluation and methodology development, In Tanner, D.G., Mwangi, W. (eds.). The Seventh Regional Wheat Workshop for Eastern, Central and Southern Africa. CIMMYT, Nakuru, Kenya, pp. 115-120.

Yesuf, A., Duga, D., Amanuel, G. (2000): Evaluation of the effects of surface drainage methods on the yield of bread wheat on Vertisols in Arsi Zone, In The Eleventh Regional Wheat Workshop for Eastern, Central and Southern Africa. CIMMYT, Addis Ababa, Ethiopia, pp. 309-315. 
Engineering International, Volume 1, No 2 (2013)

Table 1: Analysis of variance for phenology and yield components of bread wheat as influenced by planting bed and fertilization (mean square values).

\begin{tabular}{llllllll}
\hline Source of variation & & $\begin{array}{l}\text { Days to } \\
\text { Heading }\end{array}$ & $\begin{array}{l}\text { Days to } \\
\text { Maturity }\end{array}$ & $\begin{array}{l}\text { Plant } \\
\text { height }\end{array}$ & $\begin{array}{l}\text { Number of } \\
\text { spike m }{ }^{-2}\end{array}$ & $\begin{array}{l}\text { Spike } \\
\text { length }\end{array}$ & $\begin{array}{l}\text { Number of } \\
\text { spikelets } \\
\text { spike }\end{array}$ \\
\hline Replication & 2 & 12.79 & 16.79 & 59.70 & 2341.50 & 0.05 & 2.02 \\
Fertilizer (F) & 1 & $287.04^{* *}$ & $925.04^{* *}$ & $693.37^{* *}$ & $119850.67^{* *}$ & $4.58^{* *}$ & $19.49^{* *}$ \\
Planting bed (P) & 3 & $15.15^{* *}$ & $194.93^{* *}$ & $114.86^{* *}$ & $20677.33^{* *}$ & $2.49^{* *}$ & $9.39^{* *}$ \\
FxP & 3 & $4.82^{* *}$ & $9.71^{*}$ & $24.40^{*}$ & $1697.78^{*}$ & $0.59^{* *}$ & $0.95^{\text {ns }}$ \\
Error & 14 & 0.31 & 2.89 & 5.22 & 381.50 & 0.06 & 0.38 \\
\hline
\end{tabular}

$*, * *$, and $n s$ denote significant difference at $P \leq 0.05$ and $P \leq 0.01$ and non-significant differences, respectively. $d f=$ degree of freedom.

Table 2: Effect of planting bed and fertilization on phenology and plant height of bread wheat at Delanta in 2006/07.

\begin{tabular}{lcccccc}
\hline \multirow{2}{*}{ Planting bed } & \multicolumn{2}{c}{ Days to heading } & \multicolumn{2}{c}{ Days to maturity } & \multicolumn{2}{c}{ Plant height (cm) } \\
\cline { 2 - 7 } & Fertilized & Unfertilized & Fertilized & Unfertilized & Fertilized & Unfertilized \\
\hline $100 \mathrm{~cm} \mathrm{BBF}$ & $77.3 \mathrm{e}$ & $85.3 \mathrm{~b}$ & $146.0 \mathrm{~d}$ & $160.3 \mathrm{~b}$ & $93.7 \mathrm{a}$ & $79.8 \mathrm{c}$ \\
$80 \mathrm{~cm} \mathrm{BBF}$ & $77.3 \mathrm{e}$ & $86.0 \mathrm{~b}$ & $145.3 \mathrm{~d}$ & $160.0 \mathrm{~b}$ & $93.8 \mathrm{a}$ & $79.9 \mathrm{c}$ \\
RF & $80.7 \mathrm{~d}$ & $85.3 \mathrm{~b}$ & $152.3 \mathrm{c}$ & $161.7 \mathrm{~b}$ & $86.4 \mathrm{~b}$ & $76.6 \mathrm{~cd}$ \\
F & $81.7 \mathrm{c}$ & $88.0 \mathrm{a}$ & $159.3 \mathrm{~b}$ & $170.7 \mathrm{a}$ & $80.6 \mathrm{c}$ & $75.1 \mathrm{~d}$ \\
\hline CV (\%) & \multicolumn{2}{c}{0.68} & \multicolumn{2}{c}{1.08} & & 2.74 \\
\hline
\end{tabular}

Means followed by the same letter(s) for each parameter are not significantly different at $P \unlhd 0.05$.

Table 3: Effect of planting bed and fertilization on the number and length of spikes and spiklete number of bread wheat at Delanta in 2006/07.

\begin{tabular}{lccccc}
\hline \multirow{2}{*}{ Planting bed } & \multicolumn{2}{c}{ Number of spikes $\mathrm{m}^{-2}$} & \multicolumn{2}{c}{ Spike length $(\mathrm{cm})$} & $\begin{array}{c}\text { Number of } \\
\text { Spikeletes spike-1 }\end{array}$ \\
\cline { 2 - 6 } & Fertilized & Unfertilized & Fertilized & Unfertilized & Mean \\
\hline $100 \mathrm{~cm} \mathrm{BBF}$ & $505.3 \mathrm{a}$ & $332.0 \mathrm{c}$ & $8.8 \mathrm{a}$ & $7.7 \mathrm{~b}$ & $16.7 \mathrm{a}$ \\
$80 \mathrm{~cm} \mathrm{BBF}$ & $484.0 \mathrm{a}$ & $325.3 \mathrm{c}$ & $8.9 \mathrm{a}$ & $7.472 \mathrm{~b}$ & $16.8 \mathrm{a}$ \\
RF & $346.7 \mathrm{c}$ & $250.7 \mathrm{~d}$ & $7.3 \mathrm{~b}$ & $7.3 \mathrm{~b}$ & $16.1 \mathrm{~b}$ \\
F & $394.7 \mathrm{~b}$ & $257.3 \mathrm{~d}$ & $7.4 \mathrm{~b}$ & $6.5 \mathrm{c}$ & $14.2 \mathrm{c}$ \\
\hline CV $(\%)$ & \multicolumn{2}{c}{5.39} & \multicolumn{2}{c}{3.33} & 3.92
\end{tabular}

Means followed by the same letter for each parameter are not significantly different at $P \leq 0.05$. 
Engineering International, Volume 1, No 2 (2013)

Table 4: Analysis of variance for yield and yield components of bread wheat as influenced by planting bed and fertilization (Mean square).

\begin{tabular}{|c|c|c|c|c|c|c|}
\hline $\begin{array}{l}\text { Source of } \\
\text { variation }\end{array}$ & $\mathrm{df}$ & $\begin{array}{l}\text { Number } \\
\text { of kemels } \\
\text { spike }^{-1}\end{array}$ & $\begin{array}{l}\text { Thousand } \\
\text { kemel } \\
\text { weight }\end{array}$ & $\begin{array}{l}\text { Aboveground } \\
\text { biomass yield }\end{array}$ & Grain yield & $\begin{array}{l}\text { Harvest } \\
\text { index }\end{array}$ \\
\hline Replication & 2 & 12.61 & 0.26 & 136543.63 & 22795.79 & 0.64 \\
\hline Fertilization (F) & 1 & $160.42^{* *}$ & $7.56^{* *}$ & $10182945.38^{* *}$ & $5107882.67^{* *}$ & $134.85^{* *}$ \\
\hline Planting bed $(\mathrm{P})$ & 3 & $430.90^{* *}$ & $16.76^{4 *}$ & $5110993.26^{* *}$ & $2627458.11^{* *}$ & $78.59^{4 *}$ \\
\hline $\mathrm{FxP}$ & 3 & $73.03^{* *}$ & $1.21^{* *}$ & $2051283.15^{* *}$ & $705309.44 *$ & $6.25^{* *}$ \\
\hline Error & 14 & 4.73 & 0.08 & 76441.48 & 9749.17 & 0.53 \\
\hline
\end{tabular}

$*, * *$ and $n s$ denote significant difference at $P \leq 0.05$ and $P \leq 0.01$ and non-significant difference. $d f=$ degree of freedom.

Table 5: Effect of planting bed and fertilization on the number of kernels per spike and thousand grain weight of bread wheat at Delanta in 2006/07.

\begin{tabular}{lcccc}
\hline \multirow{2}{*}{ Planting bed } & \multicolumn{2}{c}{ Number of kernels per spike } & \multicolumn{2}{c}{ Thousand kernel weight (g) } \\
\cline { 2 - 5 } & Fertilized & Unfertilized & Fertilized & Unfertilized \\
\hline $100 \mathrm{~cm} \mathrm{BBF}$ & $69.3 \mathrm{a}$ & $59.0 \mathrm{~b}$ & $46.3 \mathrm{a}$ & $44.6 \mathrm{~b}$ \\
$80 \mathrm{~cm} \mathrm{BBF}$ & $71.2 \mathrm{a}$ & $59.7 \mathrm{~b}$ & $46.7 \mathrm{a}$ & $44.7 \mathrm{~b}$ \\
RF & $53.2 \mathrm{c}$ & $56.3 \mathrm{bc}$ & $43.4 \mathrm{c}$ & $42.7 \mathrm{~d}$ \\
F & $48.4 \mathrm{~d}$ & $46.4 \mathrm{~d}$ & $42.5 \mathrm{~d}$ & $42.4 \mathrm{~d}$ \\
\hline CV (\%) & \multicolumn{2}{c}{3.75} & \multicolumn{3}{c}{0.66}
\end{tabular}

Means followed by the same letter(s) for each parameter are not significantly different at $P \leq 0.05$.

Table 6: Effect of planting bed and fertilization on the aboveground biomass, grain yield and harvest index of bread wheat at Delanta in 2006/07.

\begin{tabular}{lcccccc}
\hline & \multicolumn{2}{c}{$\begin{array}{c}\text { Aboveground } \\
\text { biomass }\left(\mathrm{kg} \mathrm{ha}^{-1}\right)\end{array}$} & \multicolumn{2}{c}{ Grain yield $\left(\mathrm{kg} \mathrm{ha}^{-1}\right)$} & \multicolumn{2}{c}{ Harvest index } \\
\cline { 2 - 7 } Planting bed & Fertilized & Unfertilized & Fertilized & Unfertilized & Fertilized & Unfertilized \\
\hline $100 \mathrm{~cm} \mathrm{BBF}$ & $9866 \mathrm{a}$ & $7611 \mathrm{~b}$ & $4433 \mathrm{a}$ & $2922 \mathrm{bc}$ & $45.3 \mathrm{a}$ & $38.4 \mathrm{bc}$ \\
$80 \mathrm{~cm} \mathrm{BBF}$ & $10011 \mathrm{a}$ & $7648 \mathrm{~b}$ & $4517 \mathrm{a}$ & $2996 \mathrm{~b}$ & $45.1 \mathrm{a}$ & $39.2 \mathrm{~b}$ \\
$\mathrm{RF}$ & $7402 \mathrm{bc}$ & $6955 \mathrm{c}$ & $2778 \mathrm{dc}$ & $2446 \mathrm{e}$ & $37.5 \mathrm{c}$ & $35.2 \mathrm{~d}$ \\
$\mathrm{~F}$ & $7268 \mathrm{bc}$ & $7122 \mathrm{c}$ & $2698 \mathrm{~d}$ & $2372 \mathrm{e}$ & $37.1 \mathrm{c}$ & $33.3 \mathrm{e}$ \\
\hline $\mathrm{CV}(\%)$ & \multicolumn{3}{c}{3.46} & \multicolumn{2}{c}{3.14} & \multicolumn{2}{c}{1.88} \\
\hline
\end{tabular}

Means followed by the same letter(s) for each parameter are not significantly different at $P \unlhd 0.05$.

Table 7: Analysis of variance for $\mathrm{N}$ and $\mathrm{P}$ uptake of bread wheat as influenced by planting bed and fertilization (Mean square). 
Engineering International, Volume 1, No 2 (2013)

\begin{tabular}{llllll}
\hline $\begin{array}{l}\text { Source of } \\
\text { variation }\end{array}$ & df & GNU & SNU & GPU & SPU \\
\hline Replication & 2 & 8.78 & 7.46 & 2.02 & 0.95 \\
Fertilization (F) & 1 & $2013.73^{* *}$ & $208.92^{* *}$ & $239.98^{* *}$ & $62.11^{* *}$ \\
Planting bed (P) & 3 & $366.01^{* *}$ & $19.16^{* *}$ & $67.63^{* *}$ & $9.28^{* *}$ \\
FxP & 3 & $144.30^{* *}$ & $9.82^{* *}$ & $20.72^{* *}$ & $1.65^{* *}$ \\
Error & 14 & 2.54 & 0.61 & 0.24 & 0.21
\end{tabular}

${ }^{*}$ and ${ }^{* *}$ denote significant difference at $P \leq 0.05$ and $P \leq 0.01$, respectively. GNU \& SNU $=$ Grain $\mathcal{E}$ Straw $N$ uptake, GPU \& SPU = Grain \& Straw P uptake.

Table 8: Effect of planting bed and fertilization on nitrogen and phosphorus uptake in the grain (GNU and GPU) and straw (SNU and SPU) of bread wheat at Delanta in 2006/07.

$$
\text { GNU (kg ha-1) SNU (kg ha-1) } \quad \text { GPU }\left(\mathrm{kg} \mathrm{ha}^{-1}\right) \quad \text { SPU }\left(\mathrm{kg} \mathrm{ha}^{-1}\right)
$$

\begin{tabular}{lcccccccc} 
Planting bed & Fert. & Unfert. & Fert. & Unfert. & Fert. & Unfert. & Fert. & Unfert. \\
\hline $100 \mathrm{~cm} \mathrm{BBF}$ & $50.4 \mathrm{a}$ & $23.5 \mathrm{~d}$ & $15.5 \mathrm{a}$ & $7.5 \mathrm{de}$ & $17.4 \mathrm{a}$ & $7.9 \mathrm{c}$ & $10.4 \mathrm{a}$ & $6.2 \mathrm{~cd}$ \\
$80 \mathrm{~cm} \mathrm{BBF}$ & $51.5 \mathrm{a}$ & $24.9 \mathrm{~cd}$ & $15.6 \mathrm{a}$ & $7.4 \mathrm{de}$ & $17.6 \mathrm{a}$ & $8.1 \mathrm{bc}$ & $10.4 \mathrm{a}$ & $6.4 \mathrm{c}$ \\
$\mathrm{RF}$ & $31.1 \mathrm{~b}$ & $20.5 \mathrm{e}$ & $12.0 \mathrm{~b}$ & $7.6 \mathrm{~d}$ & $8.9 \mathrm{~b}$ & $5.9 \mathrm{~d}$ & $7.9 \mathrm{~b}$ & $5.6 \mathrm{~d}$ \\
$\mathrm{~F}$ & $27.2 \mathrm{c}$ & $18.2 \mathrm{e}$ & $9.3 \mathrm{c}$ & $6.2 \mathrm{e}$ & $8.2 \mathrm{bc}$ & $5.0 \mathrm{e}$ & $7.0 \mathrm{c}$ & $4.7 \mathrm{e}$ \\
\hline $\mathrm{CV}(\%)$ & \multicolumn{2}{c}{5.15} & \multicolumn{2}{c}{7.71} & \multicolumn{2}{c}{4.99} & \multicolumn{2}{c}{6.19}
\end{tabular}

Means followed by the same letter(s) for each parameter are not significantly different at $P \leq 0.05$. Fert. = Fertilized, Unfert. $=$ Unfertilized .

Table 9: Effect of planting bed on the apparent recovery of $N$ (ANR) and P (APR) fertilizers (mean squares).

\begin{tabular}{llll}
\hline $\begin{array}{l}\text { Sources of } \\
\text { variation }\end{array}$ & $\begin{array}{l}\text { Apparent } \mathrm{N} \\
\text { df }\end{array}$ & $\begin{array}{l}\text { Apparent } \\
\text { Recovery }\end{array}$ \\
\hline Replication & 2 & 95.89 & 16.98 \\
Planting bed & 3 & $1794.36^{* *}$ & $684.04^{* *}$ \\
Error & 6 & 11.71 & 3.58 \\
$\mathrm{CV}(\%)$ & & 7.6 & 7.1 \\
\hline$*^{*}=$ significant at $P<0.01$ level of significance. df $=$ degree of freedom
\end{tabular}


Engineering International, Volume 1, No 2 (2013)

Table 10: Effect of planting bed on nitrogen and phosphorus apparent recovery (NAR \& PAR) in bread wheat at Delanta in 2006/07.

\begin{tabular}{lcc}
\hline Planting bed & NAR $(\mathrm{kg} / \mathrm{ha})$ & PAR $(\mathrm{kg} / \mathrm{ha})$ \\
\hline $100 \mathrm{~cm} \mathrm{BBF}$ & $65.0 \mathrm{a}$ & $39.5 \mathrm{a}$ \\
$80 \mathrm{~cm} \mathrm{BBF}$ & $66.7 \mathrm{a}$ & $39.8 \mathrm{a}$ \\
$\mathrm{RF}$ & $29.2 \mathrm{~b}$ & $15.4 \mathrm{~b}$ \\
$\mathrm{~F}$ & $19.0 \mathrm{c}$ & $11.8 \mathrm{~b}$ \\
\hline Mean & 45.0 & 26.6
\end{tabular}

Means followed by the same letter in a column are not significantly different at $P \leq 0.05$.
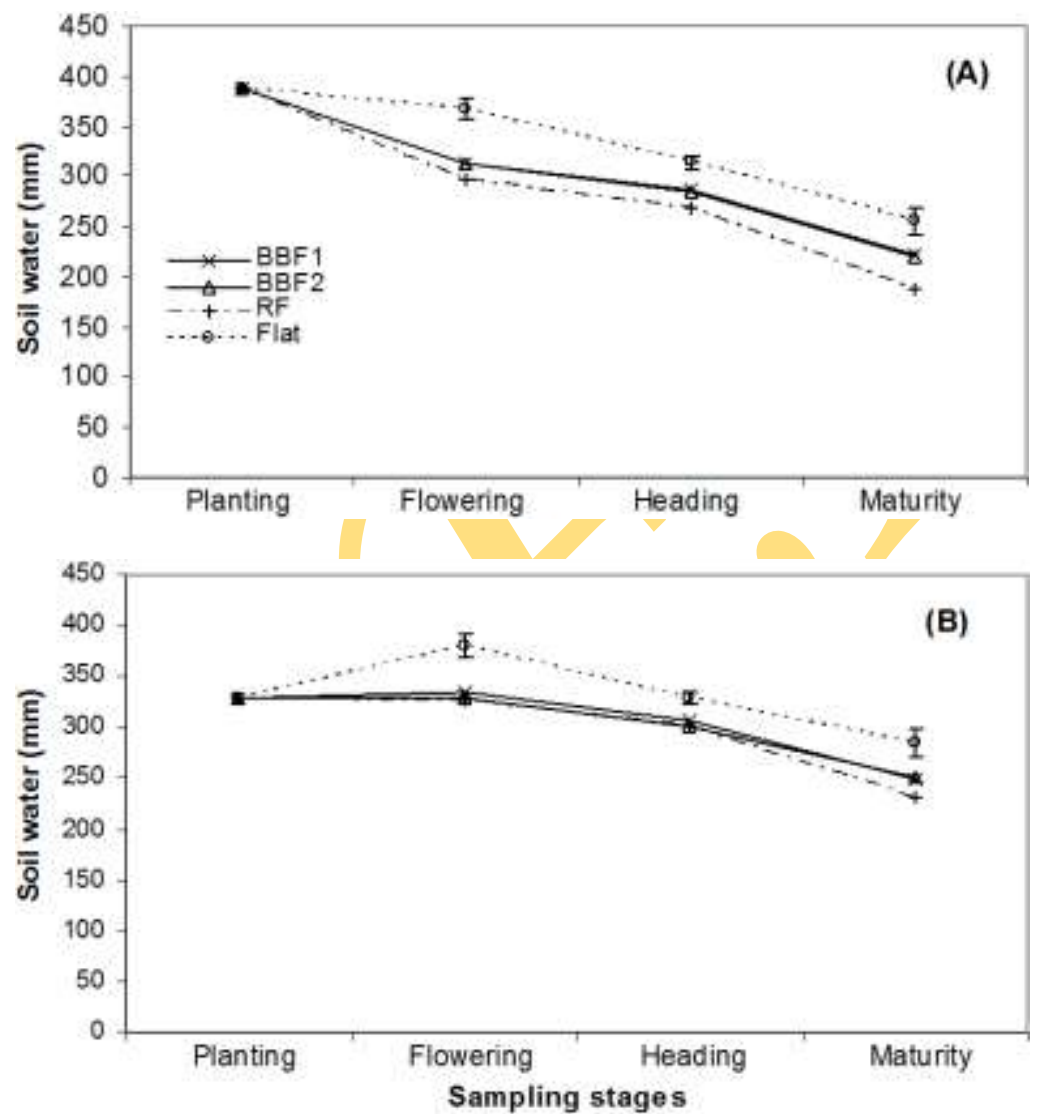

Fig. 1. Effect of planting bed on soil water content. Vertical bars indicate LSD values at $P \leq 0.05$ for each measurement period ( $A$ is at the depth of $0-30 \mathrm{~cm}$ and $B$ is at the depth of $30-60 \mathrm{~cm}$ ). BBF1 = $100 \mathrm{~cm} \mathrm{BBF}$, $B B F 2=80 \mathrm{~cm} \mathrm{BBF}$. 